\title{
THE EFFECT OF INVESTMENT, EDUCATION AND OCCUPATIONAL OPPORTUNITIES ON ECONOMIC GROWTH AND POVERTY LEVELS IN THE SARBAGITA AREA, PROVINCE OF BALI, INDONESIA
}

\author{
Negara I Gusti Ngurah Made Nata*, Utama Made Suyana \\ Faculty of Economics and Business, University of Udayana, Bali, Indonesia \\ *E-mail: nata.negara05@gmail.com
}

\begin{abstract}
Poverty is not only a concern of various countries but also the government and the people of an area in all parts of Indonesia including the Province of Bali, especially in the Sarbagita region. Various strategic policies and poverty reduction activities have been implemented directly or indirectly, both on a national and local scale. This study aims to analyze the Effects of Investment, Education, Employment Opportunities on Economic Growth, and Poverty Rate in the Sarbagita Region in the Province of Bali in 2009-2019. Data sources in this study are secondary data, obtained from the Revenue Service, Statistics Indonesia (BPS) in the Sarbagita Regional Region and the Central Statistics Agency (BPS) of the Province of Bali. The analytical tool used in this study is path analysis using Partial Least Square (SPSS) and SPSS software. The results of this study indicate that investment and education have a positive and significant effect on employment opportunities in the Sarbagita Region. Investment, education, and employment opportunities have a positive and significant impact on economic growth. Investment, education, employment opportunities, economic growth have a negative and significant effect on poverty levels. Investment, education has a non-significant effect on economic growth through employment opportunities. Investment and education have a significant effect on poverty levels through employment opportunities. Investment, education has a significant effect on poverty levels through economic growth. Job opportunities have a non-significant effect on poverty levels through economic growth.
\end{abstract}

\section{KEY WORDS}

Investment, education, employment opportunities, economic growth, poverty levels.

Poverty is a problem caused by the national conditions of a country and the global situation. One of the causes of the high level of poverty is that the global crisis occurred in various countries both developed and developing countries, and the Indonesian state also experienced an increase in poverty levels due to crises that occurred in various countries (Astrini, 2013). The poverty rate in Indonesia is also caused by various factors, namely investment levels that are still below standard, high unemployment rates, low levels of education, and slow economic growth. One of the root causes of poverty in Indonesia is the high disparity between regions due to the unequal distribution of income so that the gap between the rich and the poor in Indonesia is widening (Sianturi, 2011). The number of poor people in absolute terms is almost close to the number of poor people in 1976 which amounted to 54.2 million. Even though the economic crisis has passed, in 2003 the number still increased, namely 37.3 million people or 17.42 percent of the population of Indonesia (Mahri, 2006). Poverty reduction policy has become the main objective of the government for the welfare of its people, various policies and efforts have been made by the government to reduce poverty levels.

Growth policies need to be supplemented by specific interventions in supporting the poor, while macroeconomic stability and good governance are considered prerequisites for poverty alleviation (Steiner, 2005). The human capital theory explained the importance of improving the quality of human resources by improving education. Quality human resources can provide a multiplier effect on the development of an area, especially economic development. 
Bali is one of the provinces in Indonesia which is inseparable from the problem of poverty. Poverty is a condition where a person is unable to meet his own needs by the standard of living of his environment so that a person experiences misery in his life (Bali Construct, 2013).

Bali Province BPS data for 2005-2019 poverty levels in Bali Province, in general, are experiencing a declining trend. However, in that period, only from 2005-2006 showed an increase in the number of poor people by 0.36 percent or 15,100 people, from the previous figure of 6.72 percent to 7.08 percent. The increase in the number and percentage of poor people in 2008 was caused by the increase in fuel prices by the government. After 2009 to 2019, poverty rates in the Province of Bali show a significant downward trend. When compared with the national poverty rate, the poverty rate in the Province of Bali is still much smaller than the national poverty rate, even though the provincial government of Bali continues to work to reduce poverty in all districts/cities in the Province of Bali.

The Sarbagita region which is a national strategic area in the Province of Bali turns out to have high economic growth and is an independent urban area with an integrated regional infrastructure network system with a total population of at least 1,000,000 (one million) inhabitants. The Sarbagita regional area is by its original purpose formed with the viewpoint of economic interests based on tourism activities and in the form of a metropolitan area. The benefits of the metropolitan concept include spurring the growths of the hinterland areas of the growth center itself so that inequality between regions does not occur.

This is supported by research conducted by Wheeler (2004) in the Metropolitan United States, concluding that economic development can reduce inequality and poverty lines. However, this finding contradicts the results of a study previously conducted by Danielson and Wolpert (1992) in northern New Jersey and Sugie Lee et al. (2013) in New Jersey. The role of economic actors will never be separated in the welfare of society from the snares of poverty and economic progress, namely the government which acts as an instrument of public and fiscal policy, the private sector which plays a role in the development of investment and the community which acts as an input of factors of production and guarantees the creation of markets in the economy (Indiyani, 2013). One indicator that is often used to see the symptoms of regional economic growth is the Gross Regional Domestic Product (GRDP), the development of a region's GRDP is influenced by the real income of a region. The GRDP of a region can be influenced by the authority of its region to regulate each region. In addition to the level of investment, education, employment opportunities, and economic growth are indicators used to measure the economic performance of a region from year to year, to measure economic growth, the value of GDP used is GDP based on constant prices because by using constant prices, the effect of changes prices have been eliminated so that even though the figures that appear are the value of money from the total output of goods and services, changes in the value of GDP simultaneously show changes in the number of goods and services produced during the observation period (Afandi, 2014).

The role of the government, the community, and economic actors in restoring Bali's image in the international world especially the tourism sector as the biggest supporter of the economy (Widiarta, 2013). The main purpose of economic development efforts in addition to creating the highest growth, eliminating or reducing the level of poverty, income inequality, and the unemployment rate (Todaro, 2011). The strategy for reducing unemployment and the poor is to build jobs in an area (Tambunan, 2003).

Luntung (2006) said that increasing economic growth could create jobs that could potentially continue to grow and increase national income. The high level of education and employment or employment opportunities that exist in each region can not be separated from government policies to reduce unemployment and the welfare of the community (Deddy, 2009). Each region in carrying out its development expects high economic growth accompanied by equity so that it will improve the welfare and quality of life of its people (Anisa, 2014).

The success or failure of economic development in a region can be seen from the level of community welfare marked by increased consumption due to increased income. In reality, 
the field of economic development does not reach the welfare of low-income people (Kembar, 2010). According to Sukirno (2010), the investment can be interpreted as expenditure or investors or companies to buy capital goods and production equipment to increase the ability to produce goods and services available in the investment economy is one of the pillars of economic growth (Sjafii, 2009). Investment can be a starting point for the success and sustainability of development in the future because it can absorb labor, to open new employment opportunities for the community which in turn will have an impact on increasing community income (Hugan, 2012). After increasing employment, it is expected that an increase in production will then affect the growth of GRDP (Fitrah, 2013). There is a strong relationship between education and poverty, where through education can reduce poverty, while poverty can limit access to education (Pokharel, 2015) Education levels have an influence on poverty reduction, this is because low levels of education are one of the components causing poverty. Development in education is an important aspect that needs to be done by the government to reduce poverty.

Investment is a means for a cumulative process, leading upward in areas that have good luck and downward in areas that have bad luck (Adhisasmita, 2005), according to Kahouli (2013), urban areas that are undergoing development, increasing demand will encourage income and demand, which in turn increases investment. The reluctance of investors to invest in other sectors such as agriculture makes it difficult for other districts to compete with the Sarbagita area in attracting investment (Danawati, 2015). Efforts made by the government both provincial and central government to direct investment more evenly seem to show results (Omoniyi, 2011). Based on the previous explanation, the level of education that is right on target and the accuracy of the direction of investment to regions that can create employment opportunities might increase economic growth and GRDP.

\section{HYPOTHESES}

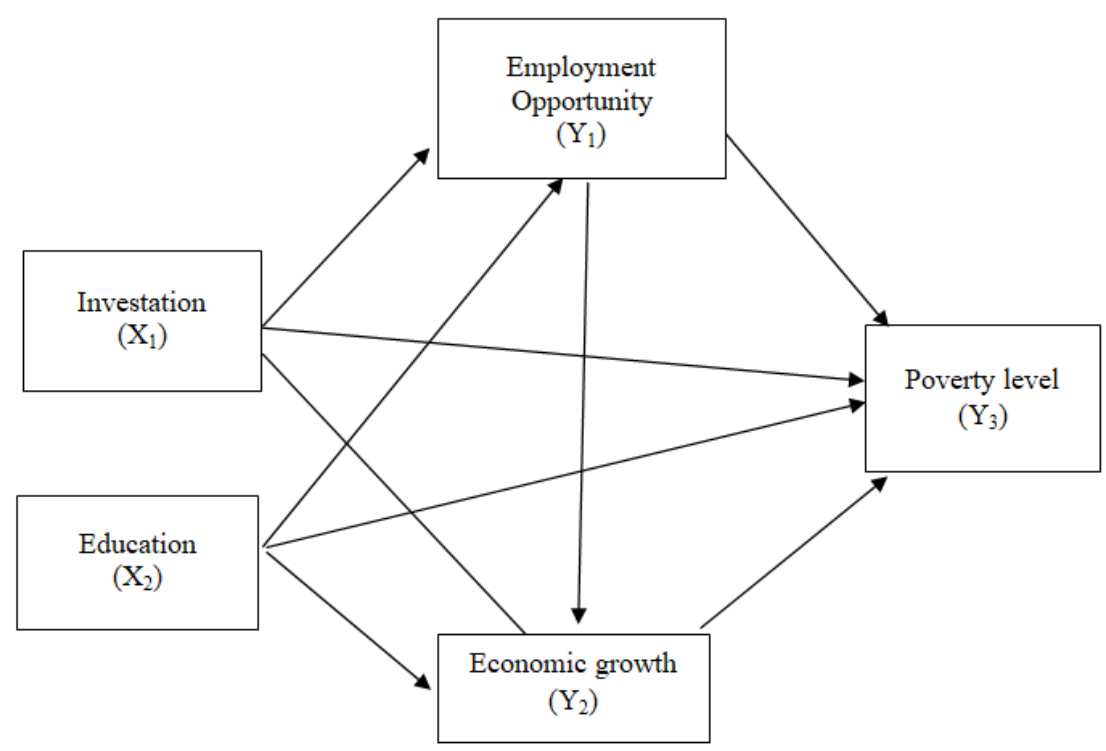

Figure 1 - Conceptual Framework

Based on the background, the formulation of the problem and literature study formulated the research hypothesis as follows.

- Investment has a positive effect on Job Opportunities in the Sarbagita Region of Bali Province.Pendidikan berpengaruh positif terhadap Kesempatan Kerja di Wilayah Sarbagita Provinsi Bali;

- Investment has a positive effect on Economic Growth in the Sarbagita Region of Bali Province; 
- Education has a positive effect on Economic Growth in the Sarbagita Region of Bali Province;

- Job Opportunities have a positive effect on Economic Growth in the Sarbagita Region of Bali Province;

- Investment has a negative effect on the Poverty Rate in the Sabagita Region of Bali Province;

- Education has a negative effect on the Poverty Rate in the Sarbagita Region of Bali Province;

- Job Opportunities have a negative effect on the Poverty Rate in the Sarbagita Region of Bali Province;

- Economic Growth has a negative effect on the Poverty Rate in the Sarbagita Region of Bali Province;

- Investment has an indirect effect on Economic Growth through Job Opportunities in the Sarnagita Region of the Province of Bali;

- Education has an indirect effect on Economic Growth through Job Opportunities in the Sarbagita Region of Bali Province;

- Investment has an indirect effect on the level of Poverty through Job Opportunities in the Sarbagita Region of the Province of Bali;

- Education has an indirect effect on poverty levels through employment opportunities in the Sarbagita Region of the Province of Bali;

- Investments have an indirect effect on Poverty through economic growth in the Sarbagita Region of the Province of Bali;

- Education has an indirect effect on poverty levels through economic growth in the Sarbagita Region of the Province of Bali;

- Job opportunities have an indirect effect on poverty levels through economic growth in the Sarbagita Region of Bali Province.

\section{METHODS OF RESEARCH}

This research is quantitative. This research is in the form of associative research, namely research that aims to determine the relationship between two or more variables. The type of data collected is secondary data, namely data on employment opportunities, investment, education, economic growth, and poverty rates in the Sarbagita region. This research was conducted in the Sarbagita regional area (Denpasar, Badung, Gianyar, Tabanan). Sarbagita region was chosen as the location of this study because the data obtained a percentage of Bali poverty levels fluctuated from 2009-2019. The type of data in this study is quantitative data which is panel data (in 2009-2019). All data in this study were collected using non-participant observation and interviews. In this study several analytical methods are used, namely descriptive statistics, Path Analysis with Partial Least Square PLS (component-based SEM) to determine the effect of investment data, employment opportunities, education levels, economic growth, and poverty levels.

\section{RESULTS AND DISCUSSION}

Based on the results of the processed data, the direct effect (path coefficient) is obtained. Results of data processing direct influence (path coefficient) variables on other variables in the study are presented in Table 1. The indirect effect of a variable on other variables in this study is presented in Table 2.

The validity of the structural model can be seen from the $\mathrm{R} 2$ of the dependent variable. For R2 in this study, there are 3 dependent variables, namely employment opportunities $(\mathrm{Y} 1)$, economic growth (Y2), and poverty level (Y3). The R2 value of the dependent variable, namely employment (Y1) of 0.677 , economic growth (Y2) of 0.828 , and poverty rate (Y3) of 0.936 which is more than 0.667 then classified as "strong", according to Chin's opinion (in Ghozali, 2011). 
Table 1 - The results of the direct influence of research variables

\begin{tabular}{ccccc}
\hline $\begin{array}{l}\text { Relationship } \\
\text { Between Variables }\end{array}$ & Coefficient & $\begin{array}{c}\text { Standard } \\
\text { Error }\end{array}$ & $\begin{array}{c}\mathrm{T} \\
\text { Statistics }\end{array}$ & P. value \\
\hline $\mathrm{X} 1 \rightarrow \mathrm{Y} 1$ & 0,675 & 0,076 & 8,854 & 0,000 \\
$\mathrm{X} 2 \rightarrow \mathrm{Y} 1$ & 0,301 & 0,092 & 3,274 & 0,001 \\
$\mathrm{X} 1 \rightarrow \mathrm{Y} 2$ & 0,280 & 0,149 & 1,879 & 0,061 \\
$\mathrm{X} 2 \rightarrow \mathrm{Y} 2$ & 0,440 & 0,101 & 4,345 & 0,000 \\
$\mathrm{Y} 1 \rightarrow \mathrm{Y} 2$ & 0,377 & 0,188 & 2,005 & 0,046 \\
$\mathrm{X} 1 \rightarrow \mathrm{Y} 3$ & $-0,212$ & 0,059 & 3,572 & 0,000 \\
$\mathrm{X} 2 \rightarrow \mathrm{Y} 3$ & $-0,376$ & 0,094 & 3,983 & 0,000 \\
$\mathrm{Y} 1 \rightarrow \mathrm{Y} 3$ & $-0,259$ & 0,072 & 3,605 & 0,000 \\
$\mathrm{Y} 2 \rightarrow \mathrm{Y} 3$ & $-0,286$ & 0,111 & 2,577 & 0,010 \\
\hline
\end{tabular}

Source: Data processed, 2020.

Table 2 - The results of the indirect effect of research variables

\begin{tabular}{lccccc}
\hline $\begin{array}{l}\text { Relationship } \\
\text { Between Variables }\end{array}$ & $\begin{array}{l}\text { Mediation Coefficient } \\
\text { Variables }\end{array}$ & Std. Er & $\begin{array}{c}\mathrm{T} . \\
\text { Statistic }\end{array}$ & P Value \\
\hline $\mathrm{X}_{1} \rightarrow \mathrm{Y}_{2}$ & $\mathrm{Y}_{1}$ & 0,254 & 0,143 & 1,774 & 0,077 \\
$\mathrm{X}_{2} \rightarrow \mathrm{Y}_{2}$ & $\mathrm{Y}_{1}$ & 0,114 & 0,076 & 1,496 & 0,135 \\
$\mathrm{X}_{1} \rightarrow \mathrm{Y}_{3}$ & $\mathrm{Y}_{1}, \mathrm{Y}_{2}$ & $-0,328$ & 0,056 & 5,801 & 0,000 \\
$\mathrm{X}_{2} \rightarrow \mathrm{Y}_{3}$ & $\mathrm{Y}_{1}, \mathrm{Y}_{2}$ & $-0,236$ & 0,080 & 2,965 & 0,003 \\
$\mathrm{Y}_{1} \rightarrow \mathrm{Y}_{3}$ & $\mathrm{Y}_{2}$ & $-0,108$ & 0,065 & 1,646 & 0,100 \\
\hline
\end{tabular}

Source: Data processed, 2020.

Notes: $X_{1}=$ Investation; $X_{2}=$ Education; $Y_{1}=$ Employment Opportunity; $Y_{2}=$ Economic growth; $Y_{3}=$ Poverty level.

\section{DISCUSSION OF RESULTS}

Effect of Investment and Education on Employment Opportunities in the Sarbagita Region of Bali Province. Statistical results show that investment and education have a positive and significant effect on employment opportunities in the Sarbagita Region of Bali Province during 2009 - 2019. This shows that investment and education can increase employment opportunities in the Sarbagita Region of Bali Province. This is consistent with Donna's (2011) research that investment has a positive and significant effect on employment opportunities in North Sumatra, where investment is one of the drivers to get income that will be used as a future. Investment increases economic output and can produce inputs. This research is by research conducted by Purwanti (2009) which states that the success of a government one of them is seen from the extent to which the government succeeded in creating jobs for its people, with high job creation will have an impact on increasing the purchasing power of the people so that ultimately welfare society will improve. Education has a positive and significant effect on employment opportunities in Semarang Regency. where education is considered as a means to get quality human resources. Because education is considered capable of producing a high-quality workforce, has a modern mindset and way of acting (Yos Merizal 2008).

Effect of Investment, education and employment opportunities on Economic Growth in the Sarbagita Region of Bali Province. Statistical results show that investment, education, and employment opportunities have a positive and significant effect on economic growth in the Sarbagita Region of Bali Province during 2009 - 2019. This shows a direct relationship between investment, education, and employment opportunities with economic growth in the Sarbagita Region of Bali Province. This is consistent with research from Zuhri (1999) that investment in both domestic and foreign investment affects economic growth both long-term and short-term. Also, Cahyani and Darsana's (2016) research has a positive and significant 
effect on economic growth, where if investment rises, economic growth will also increase. Education has a positive and significant impact on economic growth where higher education, human life will become more quality, concerning the national economy the higher the quality of life of a nation, the higher the economic growth rate of the nation (Nugroho, 2014). Growth of employment opportunities is considered as a positive factor that can spur economic growth, the more the number of the workforce through employment means that the level of production will also increase economic growth (Soebagio, 2007)

Effect of Investment, Education, Job Opportunities, Economic Growth Against Poverty Rate in the Sarbagita region of Bali Province. Statistical results show that investment, education, employment opportunities, and economic growth have a negative and significant effect on poverty levels in the Sarbagita Region of Bali Province during 2009-2019. This means if investment, education, employment opportunities, and economic growth increase, poverty in the Sarbagita Region of Bali Province will decrease. The results of previous studies from Novita (2014), investment variables have a significant negative effect on poverty in Bali Province. This means, if the investment has increased, poverty in the Province of Bali will decrease. Directly the investment variable has a significant positive effect on economic growth in Bali Province. Other research results explain that education has a negative and significant effect on poverty levels (Mok and A. Sanyal, Alemayehu, et al., 2005; Weri Nova, 2010; Budiono, 2012; Dat and Jollife, 1999 and Woolard, 2004) so this indicates the importance of education in reducing poverty. The level of employment opportunities has a negative and significant effect on poverty levels (Yanthi, 2011; Sunusi, 2014; Putra, 2016; and Vera, 2016). Economic growth is the development of activities in the economic field where these activities have an impact on increasing the goods and services produced in the community and improving people's living standards (Sukirno, 2010).

The Indirect Effects of Investment, Education on Economic Growth through Employment Opportunities in the Sarbagita Region of Bali Province. Based on statistical results show that the indirect effect of investment, and education on economic growth through employment opportunities is non-significant, it can be said that employment opportunities do not mediate the effect of investment and education on GRDP per capita in the Sarbagita region, because the absorbed workforce lacks skills, lack of education in rural areas in the Sarbagita region. Investment and education make a large contribution to the per capita GRDP as a process of creating long-term output. This is in line with the results of Haryadi's research (2009), that investment and education do not have a direct impact in the year concerned through employment opportunities, but it can only be felt for economic growth after a few years later.

The Indirect Effect of Investment and Education on Poverty Rate through Job Opportunities in the Sarbagita Region of Bali Province. Based on statistical results show that the indirect effect of investment and education on poverty levels through employment opportunities is significant, then employment opportunities fully mediate the effect of investment and education on poverty levels. Pokharel (2015), the level of education influences poverty reduction this is because high levels of education can increase employment opportunities that can reduce poverty levels. Development in education is an important aspect that needs to be done by the government to reduce poverty. Through investment in education, it will be able to improve the quality of human resources, through increasing skills and knowledge, so that it will encourage increased productivity of a person, by increasing the skills, knowledge, and productivity possessed, it will increase employment opportunities and income received which leads to an increase in people's welfare and reduction poverty. The results of this study are consistent with the results of the study put forward by Adi Putra (2018) which states that investment has a significant effect on poverty through employment opportunities where investment plays a role in the absorption of labor in one community.

Indirect Effects of Investment, Education, and Employment Opportunities on Poverty through Economic Growth in the Sarbagita Region of Bali Province. Based on statistical results show that the indirect effect of investment on poverty levels through economic growth in the Sarbagita region of Bali Province is significant. With the investment, it will have an 
impact on economic growth where with higher economic growth the poverty rate will decrease this is because in increasing the growth and development of Indonesia's economy, a strategic role is needed in the form of capital formation. The results of this study are supported by Prasetyawan ( 2017 which states that there is an influence of investment on poverty levels through economic growth. Investment plays an important role in driving the nation's economic life because capital formation increases production capacity, increases national income and creates new jobs, in terms of this will further expand employment opportunities (Todaro, 2003: 31).

Limitations. This research has been attempted and carried out by scientific procedures, however, it still has limitations, namely the limitations of research using panel data, namely the limitations of panel data according to Baltagi (2005) is a difficult data collection process, including issues of coverage and non-response. And panel data is usually only available with a short series. This means that the depiction of phenomena is very dependent on the number of individuals who tend to be infinite.

\section{CONCLUSION}

Based on the results of an analysis of the effects of investment, education, employment opportunities for economic growth, and poverty levels in the Sarbagita Region of the Province of Bali, it can be concluded that investment and education have a positive and significant effect on employment opportunities. Investment, education, and employment opportunities have a positive and significant impact on economic growth. Investment, education, employment opportunities, and economic growth have a negative and significant effect on poverty levels. Investment and education have a non-significant effect on economic growth through employment opportunities. Investment and education have a significant effect on poverty levels through employment opportunities. Investment and education have a significant effect on poverty levels through economic growth and employment opportunities have a non-significant effect on poverty levels through economic growth in the Sarbagita Region of the Province of Bali.

Based on the discussion and conclusion, the suggestion that can be made is that investment should be directed at districts/cities in the Sarbagita region which have low physical investment so that investment allocation is not concentrated in certain regions and investment allocation is also expected to be evenly distributed in all sectors. Government efforts are to continue to increase investment and allocate it well and on target for equitable development and community empowerment programs such as training and learning education and skills. The increase in labor absorption can be done by the government by increasing the GRDP and development in the region so that labor absorption increases and the poverty rate will decrease through education and training programs for the workforce conducted by the government.

\section{REFERENCES}

1. Adi Putra, I Komang Agus.2018.Analisis Pengaruh Tingkat Pengangguran Terbuka, Kesempatan Kerja, DanTingkat Pendidikan Terhadap Tingkat Kemiskinan Pada Kabupaten/Kota Di Provinsi Bali E-JurnalEkonomi Pembangunan Universitas Udayana,iVol.7, iNo.3.

2. Adhisasmita. 2005. Analisis Kesenjangan Pembangunan Regional: Indonesia 1992-2004. Jurnal Ekonomi Pembangunan Kajian Ekonomi Negara Berkembang. Vol. 9, No. 2, Hal: 129-142.

3. Afandi. 2014. Analisis Pengaruh Investasi, Tenaga Kerja, and Pengeluaran Pemerintah Terhadap Pertumbuhan Ekonomi Di Provinsi Jawa Timur (Studi KasusTahun 2001 2010). Tesis. Magister Ilmu Ekonomi \& Studi Pembangunan. Fakultas Ekonomi and Bisnis Universitas Brawijaya Malang. 
4. Asri, Putri.2013. Analisis Pengaruh Jumlah Penduduk PDRB IPM, Pengangguran Terhadap Tingkat Kemiskinan di Kabupaten/Kota Jawa Tengah. Tesis. Yogyakarta: Program Pascasarjana UGM.

5. Astrini. 2013. Pengaruh Investasi Swasta and Belanja Pemerintah Terhadap Pertumbuhan Ekonomi and Dampaknya Terhadap Kesempatan Kerja Di Kota Manado Tahun 2001-2012. Skripi. Fakultas Ekonomi and Bisnis Ekonomi Pembangunan Universitas Sam Ratulangi Manado. Atmajaya.

6. Budiono, SE, Mohamad Fahmi, SE, MT2, Harry Nurdyana S. 2012. Pendidikan and Kemiskinan Studi Kasus Provinsi Maluku Utara. BPS Kota Ternate 2. Departemen IImu Ekonomi Universitas Padjadjaran.

7. BPS Kota Denpasar. 2009. Denpasar Dalam Angka Tahun 2008. Denpasar Kota.

8. BPS Provinsi Bali. 2017. Bali DalamAngkaTahun 2016. Denpasar Kota.

9. BPS Provinsi Bali. 2018. Bali DalamAngkaTahun 2017. Denpasar Kota.

10. BPS Provinsi Bali. 2019. Bali DalamAngkaTahun 2018. Denpasar Kota.

11. Cahyani, I.G.A. Ratih. 2016. Analisis Pertumbuhan Ekonomi Bali Tahun 1996 2013.EJurnal EP Universitas Udayana Vol. 5 No 5, Mei 2016.

12. Danawati, Ni Nyoman Sri. 2015. Pengaruh Pengeluaran Pemerintah and Investasi Terhadap Kesempatan Kerja, Pertumbuhan Ekonomi Serta Ketimpangan Pendapatan Kabupaten / Kota Di Provinsi Bali. Tesis.Program Magister, Program Studi Ilmu Ekonomi, Program Pasca sarjana Universitas Udayana.

13. Danielson, Michael, and Julian Wolpert. 1992. Rapid metropolitan growth and community disparities. Growth and Change From old to a new metropolis. In Research in Community Sociology.

14. Deddy Rustiono, 2009. Analisis Pengaruh Investasi, Tenaga Kerja, and Pengeluaran Pemerintah Terhadap Pertumbuhan Ekonomi Di Provinsi Jawa Tenga. Tesis. Magister Ilmu Ekonomi \& Studi Pembangunan.Fakultas Ekonomi and Bisnis Universitas Brawijaya.

15. Gatot, SetioHarijono. 2013. Analisis Pengaruh Pengeluaran Pemerintah and Investasi Terhadap Kesempatan Kerja Melalui Pertumbuhan Ekonomi. E-Jurnal Ekonomi Pembangunan Universitas UdayanaVol. 3, No. 2, Februari 2013 (pp. 48 - 76).

16. Ghozali, Imam. 2011. Aplikasi Analisis Multivariat Dengan Program SPSS. Semarang: Badan Penerbit Universitas Diponegoro.

17. Haryadi. 2009. Respon Pertumbuhan Ekonomi Terhadap Guncangan Struktural Kebijakan Makroekonomi Indonesia: Suatu Analisis Business Cycle Dari Sisi Permintaan. Vol. 8: 63 - 76. Jurnal Ekonomi and Bisnis.

18. Hugan, Gao. 2012. Co-integration Model of Logistics Infrastructure Investment and Regional Economic Growth in Central China. International Conference on Medical Physics and Biomedical Engineering (ICMPBE2012). Volume: 33, 2012, Pages: 10361041.

19. Herman, E. 2011.The Impact of Economic Growth Process on Employment in European Union Countries. Year XIV No. 42.The Romanian Economic Journal.

20. Indiyani. 2013. Analisis Faktor-Faktor yang Mempengaruhi Kesempatan Kerjapada Kabupaten/Kota di Provinsi Jawa Tengah. Tesis. Yogyakarta: Program Pascasarjana UGM.

21. Kembar, Sri-Budhi, M. 2010. Memaknai Bias-Bias Kinerja Indikator Pembangunan Kaitannya Dengan Kesejahteraan. Pidato Pengenalan Jabatan Guru Besar Tetap dalam Bidang IImu Ekonomi Pembangunan pada Fakultas Ekonomi Universitas Udayana. Denpasar: Universitas Udayana.

22. Luntung, Suharsimi. 2006. Prosedur Penelitian Suatu Pendekatan Praktik. Jakarta: Rineka Cipta.

23. Marhaeni, A.A.I.N. and Manuati Dewi, I.G.A. 2004. Buku Ajar Ekonomi Sumber Daya Manusia. Fakultas Ekonomi Universitas Udayana.

24. Novita, Kadek Arshanti and I.G.A.P. Wirathi. 2014. Pengaruh Investasi Terhadap Pengentasan Kemiskinan Melalui Mediasi Pertumbuhan Ekonomi Provinsi Bali, E-Jurnal EP Unud, Vol.4. No. 5 Halaman. 513-524. 
25. Nugroho, SBM. 2014. Pengaruh Pendidikan Terhadap Pertumbuhan Ekonomi. Fakultas Ekonomika and Bisnis Undip, Vol. 29 No. 2 Juli 2014.

26. Omoniyi. B, Benyamin. Omobitan. Olufunsho Abayomi 2011. The Impact of Foreign Direct Investment on Economic Growth in Nigeria. International Research Journal of Finance and Economics. [Online] 73.

27. Putra, I Komang Agus Adi, Sudarsana Arka. 2016. Analisis Pengaruh Tingkat Pengangguran Terbuka, Kesempatan Kerja, and Tingkat Pendidikan Terhadap Tingkat Kemiskinan Pada Kabupaten/Kota Di Provinsi Bali, Jurusan Ekonomi Pembangunan Fakultas Ekonomi and Bisnis Unversitas. E-Jurnal EP Unud, Vol.7. No.3 Hal 416-444.

28. Pokharel, Trilochan. 2015. Poverty in Nepal: Characteristics and Challenges. Journal of Poverty, Investment and Development, 11, pp.44-56.

29. Prasetyawan, Daftian Tri dkk. 2017. Analisis Pengaruh Investasi and Tenaga Kerja Terhadap Pertumbuhan Ekonomi Serta Hubungannya Terhadap Kemiskinan di Provinsi Jawa Timur. Journal Ekuilibrium, 2017, Volume II (1): 45 -50.

30. Pratama, Yoghi Citra. (2014). Analisis Faktor-Faktor yang Mempengaruhi Kemiskinan di Indonesia. Jurnal Bisnis and Manajemen. Vol. 4. No. 2. Hal. 210-223.

31. Sjafii, Ahmad, 2009. Pengaruh Investasi Fisik and Investasi Pembangunan Manusia terhadap Pertumbuhan EkonomiJ awaTimur 1990 - 2004 Journal of Indonesia Applied Economics, Vol 3, No 1 hal $59-76$.

32. Sianturi, 2007. Analisis Pengaruh Tingkat Investasi Pendapatan Asli Daerah and Tenaga Kerja Terhadap PDRB di Jawa tengah (tesis). Megister Ilmu Ekonomi Fakultas Ekonomi Universitas Indonesia, Jakarta.

33. Todaro, Micheal P. 2006. Pembangunan Ekonomi. Edisi Kesembilan. Penerbit Erlangga, Jakarta.

34. Todaro, Michael P., and Smith, Stephen C. 2011.Economic Development. Eleventh Edition. United States: Addison Wesley.

35. Vera, Herry. 2016. Pengaruh Tingkat Pendidikan, Kesehatan Terhadap Produktivitas and Jumlah Penduduk Miskin Di Provinsi Kalimantan Barat. Tesis. Program Magister Ilmu Ekonomi Universitas Tanjung Pura Pontianak.

36. Wheeler, M. Stephen. (2004). Planning for Sustainability Creating Livable, Equitable, and Ecological Community. New York: Routledge.

37. Yos, Merizal. 2008. Pengaruh Pendidikan, Upah Minimum Kabupaten, and Kesempatan Kerja terhadap Pengangguran Terdidik di Kabupaten Semarang. Skripsi Ekonomi Universitas Diponogoro Semarang. 